\title{
PENDUGAAN MASA SIMPAN TAHU DENGAN PENAMBAHAN ANTIOKSIDAN EKSTRAK KULIT PISANG
}

\author{
Myra Wardati Sari, Hida Arliani Nur Anisa \\ Teknik Kimia, Politeknik TEDC Bandung, Jl. Pesantren Km.2 Cimahi 40513 \\ Email : myrawardatisari@poltektedc.ac.id
}

\begin{abstract}
Abstrak
Indonesia adalah negara tropis yang banyak menghasilkan tanaman pangan, termasuk kedelai. Kadar protein yang tinggi dan kemudahan untuk diolah menjadikan variasi olahan makanan kedelai beragam, tahu merupakan yang popular diantaranya. Namun sayangnya, tahu memiliki masa simpan yang rendah. Hal ini mengakibatkan oknumoknum tak bertanggung jawab menggunakan pengawet non makanan untuk memperpanjang masa simpan tahu selama proses pemasaran. Oleh karena itu dibutuhkan pengawet alami yang murah dalam proses pembuatan tahu. Ekstrak kulit pisang yang mengandung senyawa antioksidan alami diharapkan mampu memperpanjang umur simpan tahu dan meningkatkan nilai jualnya. Penelitian ini merupakan lanjutan dari penelitian sebelumnya, yaitu perendaman tahu dalam larutan ekstrak kulit pisang dan pembuatan tahu dengan penambahan ekstrak kulit pisang sebagai anti oksidan. Tahapan dalam peneltiian ini adalah: 1) membuat ekstrak kulit pisang melalui metode maserasi dengan pelarut senyawa alkohol; 2) membuat tahu dengan penambahan ekstrak kulit pisang dengan variasi konsentrasi $2 \%$ dan $4 \% ; 3$ ) membuat tahu polos (tanpa penambahan ekstrak kulit pisang) dan merendamnya dalam larutan ekstrak kulit pisang dengan variasi konsnetrasi $2 \%$ dan $4 \%$; 4) dilakukan uji mikrobiologi angka lempeng total (ALT). Hasil pengujian ALT yang diperoleh menunjukkan semakin tinggi konsentrasi ekstrak kulit pisang, pertumbuhan bakterinya semakin rendah. Hasil terbaik nampak pada variasi "pencampuran" dengan pelarut maserasi metanol dan konsentrasi antioksidan ekstrak kulit pisang sebesar $4 \%$ didapatkan $2,9 \times 10^{2}$ koloni/gram di hari keempat penyimpanan. Jika dilakukan ekstrapolasi kurva untuk pendugaan masa simpan secara kasar, hanya ditinjau dari faktor pertumbuhan bakteri, dan dibandingkan dengan batas maksimum cemaran mikroba dalam makanan, nilai tersebut memiliki masa simpan 75 hari.
\end{abstract}

Kata kunci: ALT ; antioksidan ; ekstrak kulit pisang ; tahu

\begin{abstract}
Indonesia is a tropical country that produces a lot of food crops, including soybeans. The high protein content and easy processing of soybeans make various variations of soybean food processed, tofu is one of the most popular. But unfortunately, tofu has a short shelf life. This condition encourages irresponsible people to use nonfood preservatives as tofu preservatives in their marketing to extend shelf life of tofu. Therefore, inexpensive natural preservatives are needed in the process of making tofu. Banana peel extract which contains natural antioxidant compounds is expected to be able to extend the shelf life of the tofu and increase its selling value. This research is a continuation of previous research, namely soaking tofu in banana peel extract solution and making tofu with the addition of banana peel extract as an anti-oxidant. The stages in this research were: 1) making banana peel extract through the maceration method with alcohol compound solvents; 2) making tofu with the addition of banana peel extract with various concentrations of $2 \%$ and $4 \%$; 3 ) making plain tofu (without the addition of banana peel extract) and soaking it in a solution of banana peel extract with a concentration variation of $2 \%$ and $4 \%$; 4) a total plate count (ALT) microbiological test was performed. The ALT test results obtained showed that the higher the banana peel extract concentration, the lower the bacterial growth was. The best results were seen in the variation of "mixing" with methanol maceration solvent and 4\% antioxidant concentration of banana peel extract obtained $2.9 \times 10^{2}$ colonies/gram on the fourth day of storage. if we extrapolate the bacterial growth curve and compare it with the maximum limit of microbial contamination in food, we will get an estimated shelf life of this tofu's variation 75 days.
\end{abstract}

Keywords: antioxidant ; banana peel extract ; tofu ; TPC 


\section{Pendahuluan}

Indonesia adalah negara tropis, dimana masyarakatnya banyak memanfaatkan tanah subur negara ini sebagai mata pencaharian. Salah satu tanaman yang banyak dibudidayakan di Indonesia adalah kedelai, produksinya pada tahun 2015 mencapai 963.183 ton (BPS, 2020). Kedelai merupakan tanaman multiguna yang mengandung banyak protein mencapai $377 \mathrm{~g} / \mathrm{kg}$ berat kering (Jayanegara, 2016), sehingga dapat dimanfaatkan untuk bahan pangan, baik dimakan langsung maupun diolah menjadi berbagai jenis makanan untuk menambah nilai jualnya. Makanan olahan kedelai yang paling populer adalah tahu (Wicaksono, 2020).

Pembuatan tahu yang mudah, menjadikannya banyak diproduksi di Indonesia sebagai sumber penghasilan masyarakat. Namun, daya simpan yang rendah, hanya dapat bertahan satu hari di suhu ruang (Indrawijaya, 2017; Harti, 2013), masih menjadi kendala dalam pemasaran produk tahu dan menyulitkan pedagang yang tidak memiliki fasilitas pendingin untuk menunjang penjualan. Kelemahan produk tahu namun tingginya permintaan pasar, membuatnya membuka peluang bagi pihak-pihak tidak bertanggungjawab untuk menggunakan bahan pengawet non-pangan untuk memperpanjang masa simpan tahu yang dipasarkan. Oleh karena itu, dibutuhkan modifikasi proses, metode maupun bahan tambahan dalam produksi tahu. Bahan tambahan yang dibutuhkan adalah pengawet alami yang murah dan mudah digunakan sehingga tidak mengganggu ongkos produksi dan harga tahu bagi konsumen tetap terjangkau.

Salah satu komponen alami yang dapat berfungsi sebagai pengawet bahan pangan adalah antioksidan (Sanchez, 2017). Antioksidan merupakan salah satu bentuk pengawet alami (Carocho, 2014) yang dapat ditambahkan relatif aman ke dalam bahan pangan untuk memperpanjang umur simpan.

Kulit pisang merupakan limbah/bahan sisa yang diketahui mengandung zat flavonoid dari golongan fenolik (UK Essay, 2018) yang merupakan metabolit sekunder dan berfungsi sebagai antioksidan. Penggunaan ekstrak antioksidan bisa menjadi efektif dalam memperpanjang masa simpan bahan makan dan meningkatkan mutu dan nilai jualnya. Maka dari itu, dilakukan ekstraksi kulit pisang untuk mendapatkan filtrat antioksidannya yang nantinya akan digunakan sebagai pengawet bahan pangan tahu. Diharapkan ekstrak kulit pisang ini dapat menjadi bahan tambahan pangan (BTP) alami yang murah dan mudah dibuat, sehingga efektif untuk digunakan dalam inovasi pembuatan tahu.

Pembuatan ekstrak kulit pisang ini pernah dilakukan oleh Riani, dkk., 2019 dengan maserasi kulit pisang menggunakan pelarut air. Pada penelitian kali ini, dilakukan modifikasi dengan maserasi menggunakan pelarut golongan alkohol untuk mendekati kepolaran zat antioksidan yang diinginkan, diharapkan efektivitas keterambilan (yield) antioksidan dalam ekstrak kulit pisang lebih tinggi, begitu pula dengan daya pengawetan dan daya hambat terhadap pertumbuhan bakteri akan lebih baik.

Salah satu faktor yang mempengaruhi masa simpan suatu produk pangan adalah pertumbuhan bakteri. Parameter analisa yang mendukung fakor tersebut diantaranya adalah Angka Lempeng Total (ALT). Maka dalam penelitian kali ini, dilakukan pendugaan umur simpan tahu yang telah ditambahkan ekstrak kulit pisang sebagai antioksidan dengan menggunakan metode ALT. Analisa ALT akan menghasilkan nilai banyaknya bakteri yang dapat tumbuh dalam sampel yang diuji.

\section{Bahan dan Metode Penelitian Bahan}

Bahan utama yang digunakan dalam percobaan ini adalah kulit pisang raja bulu sebanyak $2,5 \mathrm{~kg}$ yang diambil dari Pasar Cihanjuang, Cimahi. Selanjutnya adalah bahan pendukung seperti cuka dan kacang kedelai untuk pembuatan tahu. Media nutrient agar untuk analisa ALT.

\section{Alat}

Peralatan yang digunakan dalam percobaan ini adalah rotary vacuum evaporator, alat-alat gelas, blender, neraca analitik, cawan petri, dan inkubator.

\section{Prosedur}

Prosedur yang dilakukan dalam penelitian kali ini terbagi atas tiga tahap, yaitu:

\section{Tahap Persiapan}

Tahap persiapan ini yang dilakukan meliputi :

1. Dilakukan pembuatan ekstrak kulit pisang raja bulu sebagai sumber antioksidan dengan metode maserasi menggunakan pelarut senyawa alkohol : metanol dan etanol.

2. Dilakukan uji aktivitas antioksidan pada ekstrak kulit pisang yang telah dibuat. Jika nilai yang didapatkan baik, maka antioksidan ekstrak kulit pisang siap digunakan.

3. Dilakukan produksi tahu.

4. Dilakukan perlakuan terhadap tahu (pencampuran dan perendaman dengan antioksidan ekstrak kulit pisang).

5. Dilakukan uji aktivitas antioksidan tahu dengan perlakuan ekstrak kulit pisang

Pada penelitian ini ditekankan pada pengujian Angka Lempeng Total (ALT) yang dilakukan di Laboratorium Teknologi Pangan Fakultas Teknik Universitas Pasundan dengan tahapan sebagai berikut:

\section{Pembuatan Media}

Dibuat media nutrient agar dengan dilarutkan dalam aquadest, yang selanjutnya disterilisasi dalam autoklaf. 


\section{Isolasi dan Pengamatan}

Tahap ini dilakukan dengan metode tuang dan diisolasi pada suhu $30^{\circ} \mathrm{C}$ selama 72 jam sesuai prosedur dalam SNI 7388-2009. Pertumbuhan koloni mikroba diamati dengan menggunakan colony counter.

\section{Hasil dan Pembahasan}

Berdasarkan penelitian yang telah dilakukan terdahulu (Riani, dkk., 2019; Sari, dkk., 2019), pada percobaan kali ini dilakukan modifikasi pelarut maserasi. Variasi perlakuan yang dilakukan pada percobaan ini meliputi :

a. Tahu yang telah dicampur ekstrak kulit pisang $2 \%$ dan $4 \%$, pada proses pembuatannya. Ekstrak kulit pisang dibuat dengan proses maserasi berpelarut etanol dan metanol.

b. Tahu yang telah direndam larutan ekstrak kulit pisang konsentrasi $2 \%$ dan $4 \%$. Ekstrak kulit pisang dibuat dengan proses maserasi berpelarut etanol dan metanol.

Berdasarkan variasi perlakuan tersebut, didapatkan hasil yang disajikan pada pembahasan berikut.

\section{A. Pencampuran}

Pada perlakuan variasi pencampuran, kulit pisang yang telah halus dimaserasi menggunakan pelarut metanol dan etanol sehingga menjadi ekstrak kulit pisang, lalu dilakukan evaporasi untuk memekatkan ekstrak tersebut. Ekstrak pekat kulit pisang tersebut selanjutnya dicampurkan bersama dengan bahan-bahan pembuatan tahu dengan konsentrasi $2 \%$ dan $4 \%$. Pemilihan konsentrasi pencampuran yang rendah mengacu pada SNI 01-0222-1995 tentang aturan bahan tambah pangan. Nilai angka lempeng total (ALT) yang didapatkan oleh variasi perlakuan ini disajikan pada Gambar 1 .

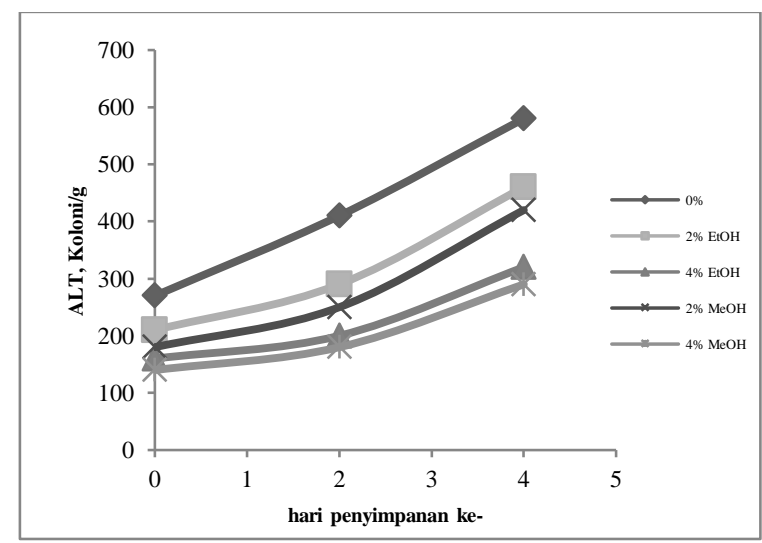

Gambar 1 Angka lempeng total untuk tahu yang dicampur dengan ekstrak kulit pisang

Pada perlakuan "pencampuran", didapatkan nilai ALT terbaik ada pada variasi pelarut maserasi metanol dengan konsentrasi ekstrak kulit pisang 4\%. Nilai yang

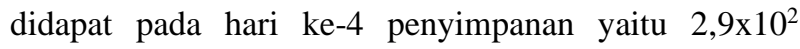
koloni/gram. Nilai ini di bawah angka batas maksimum cemaran mikroba dalam bahan pangan (SNI 7388: 2009), yaitu $5 \times 10^{4}$ koloni/gram. Jika dilakukan ekstrapolasi terhadap kurva variasi pelarut maserasi metanol dengan konsentrasi ekstrak kulit pisang 4\%, maka untuk mendapatkan nilai maksimum $5 \times 10^{4} \mathrm{koloni} /$ gram, waktu penyimpanan nya adalah 75 hari. Hal ini tentu merupakan berita baik untuk memperpanjang masa simpan tahu.

\section{B. Perendaman}

Pada perlakuan variasi perendaman, kulit pisang yang telah halus dimaserasi menggunakan pelarut metanol dan etanol sehingga menjadi ekstrak kulit pisang, lalu dilakukan evaporasi untuk memekatkan ekstrak tersebut. Ekstrak pekat kulit pisang tersebut selanjutnya dilarutkan dalam air sehingga menjadi larutan ekstrak kulit pisang. Kosentrasi larutan ekstrak kulit pisang yang dipilih adalah $2 \%$ dan $4 \%$. Selanjutnya tahu polos (tanpa penambahan ekstrak kulit pisang) direndam dalam larutan ekstrak kulit pisang tersebut dan disimpan sambil diamati perubahan yang terjadi secara visual.

Pemilihan konsentrasi pencampuran yang rendah mengacu pada SNI 01-0222-1995 tentang aturan bahan tambah pangan. Nilai angka lempeng total (ALT) yang didapatkan oleh variasi perlakuan ini disajikan pada Gambar 2.

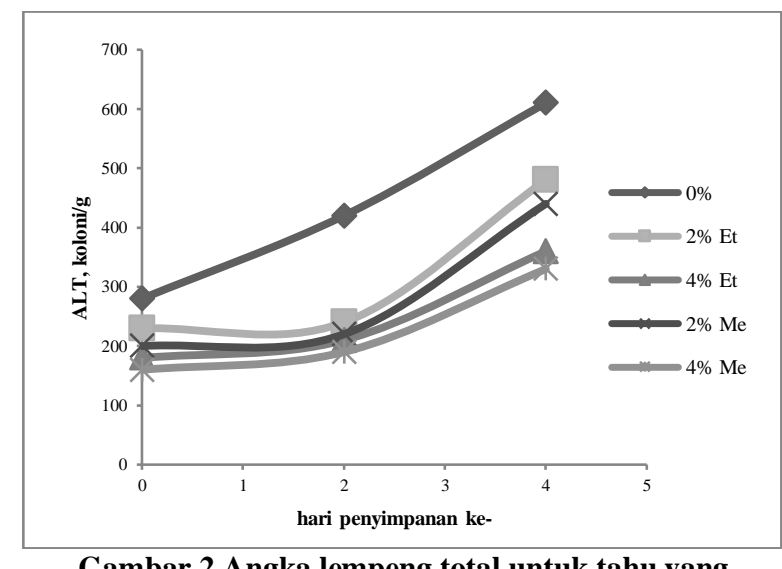

Gambar 2 Angka lempeng total untuk tahu yang direndam larutan ekstrak kulit pisang

Pada perlakuan "perendaman", didapatkan nilai ALT terbaik ada pada variasi pelarut maserasi metanol dengan konsentrasi ekstrak kulit pisang 4\%. Nilai yang didapat pada hari ke-4 penyimpanan yaitu $3,3 \times 10^{2}$ koloni/gram. Nilai ini berada di bawah angka batas maksimum cemaran mikroba dalam bahan pangan (SNI 7388: 2009), yaitu $5 \times 10^{4}$ koloni/gram. Dengan melakukan ekstrapolasi terhadap kurva variasi pelarut maserasi metanol dengan konsentrasi ekstrak kulit pisang $4 \%$, untuk mendapatkan perkiraan waktu simpan hingga mencapai jumlah koloni batas maksiumum SNI 7388:2009, maka didapatkan waktu penyimpanan nya adalah 60 hari. 
Angka perkiraan masa simpan yang didapatkan variasi "pencampuran" lebih lama dibandingkan dengan variasi "perendaman". Dapat dikatakan penambahan antioksidan dalam produksi tahu lebih efektif dilakukan jika ekstrak kulit pisang dicampur langsung saat proses pembuatan tahu.

Hal ini dikarenakan pada proses pencampuran, ekstrak kulit pisang lebih terhomogenisasi dalam tahu dibandingkan dengan hanya direndam menggunakan larutan ekstrak kulit pisang. Pada proses pencampuran, zat aktif antioksidan dapat terabsorpsi hingga merata ke seluruh bagian tahu hingga ke dalamnya, sedangkan pada proses perendaman, zat aktif antioksidan dalam ekstrak kulit pisang hanya menjangkau bagian luar tahu yang terendam (hanya mengadsorpsi di bagian permukaan saja). Perpindahan massa zat aktif antioksidan ekstrak kulit pisang yang berbentuk cair mengalami difusi ke dalam padatan tahu (Treybal, 1980) dan terjadi proses adsorpsi (pada proses rendam) atau absorpsi (pada proses campur), namun kecepatan dan aktivitas difusi peristiwa ini tidak masuk dalam lingkup percobaan ini. Faktor lain yang mempengaruhi efektivitas proses rendam dan campur adalah kelarutan ekstrak kulit pisang dalam air saat dibuat larutan rendaman. Menurut pengamatan visual, ekstrak kulit pisang yang dimaserasi dengan menggunakan metanol lebih mudah larut dalam air saat dijadikan larutan rendaman dibandingkan dengan maserasi menggunakan etanol. Hal ini dikarenakan panjang rantai mempengaruhi kelarutan dalam air, semakin panjang rantai maka kelarutan dalam air semakin menurun (Libretexts, 2020; Fessenden, 1986). Faktor-faktor tersebut mengakibatkan fungsi antioksidan untuk menghambat pertumbuhan bakteri pada proses perendaman, tidak maksimal.

Tabel 1 Hasil Uji Senyawa Fitokimia Kulit Pisang

\begin{tabular}{lc}
\hline Jenis Uji & Hasil \\
\hline Alkaloid & + \\
\hline Tanin & + \\
\hline Flavonoid & + \\
\hline Saponin & - \\
\hline Steroid & + \\
\hline Triterpenoid & + \\
\hline Antosianin & - \\
\hline & Sumber : Riani,Y., dkk., 2019
\end{tabular}

Angka Lempeng Total (ALT) yang didapatkan baik pada variasi perlakuan perendaman maupun pencampuran, menunjukkan, semakin besar konsentrasi , maka nilai pertumbuhan bakteri (yang diwakilkan oleh parameter ALT) semakin kecil. Hal ini sejalan dengan penelitian terdahulu Yanti, 2014 dalam Fitriahani, 2017. Dengan demikian senyawa aktif antioksidan dalam kulit pisang, tersaji dalam tabel 1, dapat membantu menghambat pertumbuhan bakteri di produk tahu.
Senyawa fitokimia dalam kulit pisang bertindak sebagai antioksidan sekaligus juga dapat menghamnbat pertumbuhan bakteri (Sudira, 2011). Senyawa fitokimia merupakan antioksidan non enzimatis (Moharram, 2014) yang menghambat pertumbuhan bakteri dengan cara merusak dinding sel dan membentuk ikatan protein fungsional mikroba (Ningsih, 2016; Sudira, 2011); atau dengan cara membentuk lapisan seperti lilin untuk menolak kehadiran mikroba (Ningsih, 2016). Antioksidan yang diambil dari tanaman juga lebih aman digunakan dalam makanan dan memiliki tingkat efek samping yang minimal (Chandra P., dkk., 2020).

Berdasarkan penelitian yang telah dilakukan maka dapat diambil kesimpulan bahwa :

1. Ekstrak kulit pisang terbukti mengandung antioksidan yang dapat menghambat pertumbuhan mikroba yang dibuktikan dengan pengujian ALT.

2. Metode "pencampuran" ekstrak kulit pisang dalam pembuatan tahu sebagai antioksidan lebih efektif dibandingkan dengan metode "perendaman".

3. Secara kasar, ditinjau dari parameter ALT, maka daya simpan terbaik yang mampu dicapai tahu dengan penambahan antioksidan ekstrak kulit pisang variasi "pencampuran" konsentrasi ekstrak kulit pisang 4\% dan "perendaman" variasi konsentrasi larutan ekstrak kulit pisang 4\% secara berurutan adalah 75 hari dan 60 hari.

\section{Ucapan Terima Kasih}

Penelitian ini merupakan penelitian yang didanai oleh Kementerian Riset dan Pengabdian Masyarakat Direktorat Jenderal Penguatan Riset, Teknologi, dan Pendidikan Tinggi melalui program hibah penelitian dosen pemula (PDP) pendanaan tahun 2020.

\section{Daftar Pustaka}

1. BPS. 2020. Produktivitas Tanaman Pangan 2013 2015.

https://www.bps.go.id/indicator/53/22/1/produktivi tas.html .diakses tanggal 11 November 2020

2. Carocho, M., M.F.Barreiro, P.Morales, dan I.C.F.R. Ferreira. 2014. Adding Molecules to Food, Pros and Cons: A Review on Synthetic and Natural Food Additives. Comprehensive Reviews in Food Science and Food Safety. 13. 377-399. doi: 10.1111/1541-4337.12065

3. Chandra P., Rakesh Kumar Sharma, Daljit Singh Arora. 2020. Antioxidant compounds from microbial sources: A review. Food Research International. Volume 129. ISSN 0963-9969

4. https://doi.org/10.1016/j.foodres.2019.108849

5. Fessenden, R.J. 1986. Kimia Organik. Jilid 1. Edisi ketiga. Erlangga. Jakarta.

6. Fitriahani, F. 2017. Uji Aktivitas Antibakteri Ekstrak Etanol 70\% Limbah kulit Pisang (Musa 
acuminate x Musa balbisiana cv Candi) Terhadap Bakteri Staphylococcus aereus dan Escherichia coli. Skripsi. Universitas Islam Negri Maulana Malik Ibrahim. Malang

7. Harti,A, A. Nurhidayati, dan D. Handayani. 2013. Potensi Chito-oligosaccharide (COS) Sebagai Prebiotik dan Pengawet Alami Dalam Pembuatan tahu Sinbiotik. Prosiding SNST ke-4. Fakultas Teknik Universitas Wahid Hasyim Semarang.

8. Indrawijaya, B., A. Paradiba, dan S.A.Murni. 2017. Uji Organoleptik dan Tingkat Ketahanan Produk Tahu Berpengawet Kitosan. Jurnal Ilmiah Teknik Kimia UNPAM. 1(2).

9. Jayanegara, A., S. P. Dewi, dan M. Ridla. 2016. Nutrient Content, Protein Fractionation, and Utilization of Some Beans as Potential Alternatives to Soybean for Ruminant Feeding. Media Peternakan. 39(3):195-202. DOI: 10.5398/medpet.2016.39.3.195

10. Libretext. 2020. Properties of Alcohols. https://chem.libretexts.org/Courses/Eastern_Menn onite_University/EMU\%3A_Chemistry_for_the_L ife_Sciences_(Cessna)/14\%3A_Organic_Compou nds_of_Oxygen/14.03_Physical_Properties_of_Al cohols. diakses tanggal 11 November 2020.

11. Moharram, H.A., M.M. Youssef. 2014. Methods for Determining the Antioxidant Activity: A Review. Alex. J. Fd. Sci. \& Technol. 11(1): 31-42

12. Ningsih, D., Zusfahair dan D. Kartika. 2016. Identifikasi Senyawa Metabolit Sekunder Serta Uji Aktivitas Ekstrak Daun Sirsak Sebagai Antibakteri. Molekul. 11(1):101-111

13. Riani, Y., H.A.N. Anisa, dan M.W. Sari. 2019. Pengaruh Perendaman Tahu dalam ekstrak Kulit Pisang Terhadap Aktivitas Antioksidan. Prosiding Seminar Nasional Soebardjo Brotohardjono XV. UPN "Veteran" Jawa Timur. C.2-1 - C.2-6

14. Sánchez, N.F.S., R.S. Coronado, R.V.Blanco, B.H.Carlos, dan P.C. G.Mendoza. 2017. Natural Antioxidant Extracts As Food Preservatives. Acta Sci. Pol. Technol. Aliment. 16(4): 361-370.

15. Sari, M.W., H.A.N. Anisa, dan Y. Riani. 2019. Pengujian Angka Lempeng Total (ALT) Tahu dengan Penambahan Ekstrak kulit Pisnag sebagai Antioksidan. Prosiding Seminar Nasional Soebardjo Brotohardjono XV. UPN "Veteran" Jawa Timur. D.1-1 - D.1-5

16. SNI 010222:1995 Bahan Tambahan Makanan

17. SNI 7388: 2009 Batasan Maksimum Cemaran Mikroba dalam Pangan

18. Sudira I., I. Merdana, dan I. Wibawa. 2011. Uji Daya Hambat Ekstrak Daun Kedondong (Lannea grandis Engl.) terhadap Pertumbuhan Bakteri Erwina carotovora. Buletin Veteriner Udayana. 3(1): 45-50. ISSN : 2085-2495

19. Treybal, R.E. 1980. Mass Transfer Operations, 3rd Edition. McGraw-Hill Companies, Inc, New York.
20. UK Essays. 2018. Antioxidant Activity of Banana Peel. [online]. Available from: https://www.ukessays.com/essays/biology/highantioxidant-banana-peel-extract-using-solventextraction-biology-essay.php?vref=1 diakses tanggal 11 November 2020

21. Wicaksono A., dan D. Yuguslavia. 2020. The Production Process of Tofu using Raw Materials To Keep Quality.International Journal of Transportation and Infrastructure. (IJTI). 68-71 